\title{
Implications of Local Knowledge Construction in Empowerment Practices of Women's Groups at Batik Liza Mangrove Studio, Pematang Johar Village, Deli Serdang Regency
}

\author{
Mujahiddin $^{1}$, Yurisna Tanjung ${ }^{2}$, Nurhasanah Nasution ${ }^{3}$ \\ 1,2,3 Universitas Muhammadiyah Sumatera Utara, Indonesia \\ Mujahiddin@umsu.ac.id
}

\begin{abstract}
At present, the global development goals stated in the Sustainable Development Gols (SDGs), the empowerment agenda is still the main focus, especially with regard to empowering women's groups. Although it does not explicitly emphasize women's empowerment in $i$, in many cases community empowerment practices through ADD always place poor and under-prosperous women as the main participants. In Pematang Johar Village, Deli Serdang Regency, the practice of empowering women's groups is carried out by developing entrepreneurship based on the local potential of the village, namely through batik crafts. This program begins with the formation of a women's batik group with the aim that the batik group formed can produce batik works with local characteristics which are then given the name "Batik Sawah". The research design used a qualitative research design with a case study approach to a group of women in the Batik Liza Mangrove Studio, Pematang Johar Village, Deli Serdang Regency. The data in this study were collected using in-depth interviews with each research informant. The research informants were selected using a purposive sampling approach. Based on the results of the discussion above, it can be concluded that the batik training given to the women's batik groups makes them self-empowered in the form of authority, knowledge and abilities. This condition makes them able to fulfill their daily needs physically, economically and socially. The impact of the practice of empowering women at the Liza Manggrove Batik Studio has only succeeded in improving family welfare subjectively. This is because the income generated from batik activities can only be used to meet the primary needs of the family and has not been able to meet other needs.
\end{abstract}

Keywords

local construction; women's

groups empowerment

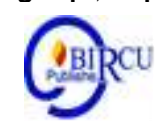

\section{Introduction}

Empowerment can be interpreted as giving power from an empowered group to a group that is categorized as helpless. This meaning can be seen from the explanation of Ife \& Tesoriero (2008) which states that; Empowerment is inevitably about power either by individuals or groups who use the opportunity to take power into their hands, distributing it from the "haves" to the "dispossessed groups" and so on. Suharto (2009) then divides empowerment into two forms, namely; first, empowerment as a process which is interpreted as a series of activities to strengthen the empowerment of weak groups in society, including individuals experiencing poverty problems. 
At present, the global development goals stated in the Sustainable Development Gols (SDGs), the empowerment agenda is still the main focus, especially with regard to empowering women's groups. This can be seen from the fifth point of the SDGs development goals which place a gender equality agenda. In Indonesia, this point on gender equality is translated into a Regional Medium Term Development Plan (RPJMD) policy which is directed at improving the quality of life and role of women in development, as well as protecting women from various acts of violence. One of the policy points is to open and increase access to women in poor or disadvantaged areas and in rural areas through economic empowerment.

In rural areas, women's empowerment practices have begun to be developed through the provision of Village Fund Allocation (ADD). Although it does not explicitly emphasize women's empowerment in it, in many cases community empowerment practices through ADD always place poor and under-prosperous women as the main participants. In some villages, for example, developing village tourism through ADD can be said to be successful in empowering village communities, especially women's groups (Hendryantoro, 2014; Mustangin et al, 2017). The existence of empowerment practices for women's groups ultimately has an effect on increasing family income. Mualif in Dewi (2015) states that the practice of empowering women can have an economic impact on the family, which is marked by an increase in family income and success in fulfilling the daily needs of the family. In addition, the practice of empowering women also has an impact on increasing women's confidence in interacting with society because empowered women will have an independent spirit (Mualif in Dewi, 2015).

In Pematang Johar Village, Deli Serdang Regency, the practice of empowering women's groups is carried out by developing entrepreneurship based on the local potential of the village, namely through batik crafts. This program begins with the formation of a women's batik group with the aim that the batik group formed can produce batik works with local characteristics which are then given the name "Batik Sawah". The name "Batik Sawah" was originally chosen because the motif on the batik work is characterized by rice growing (see Figure 1.1). In addition, the choice to use the name "Batik Sawah" is also because Pematang Johar Village has the potential for rice fields with an area of 1,750 hectares of rice fields from a total area of 2,217.84 hectares. With this area, Pematang Johar Village has made rice fields its main potential base.
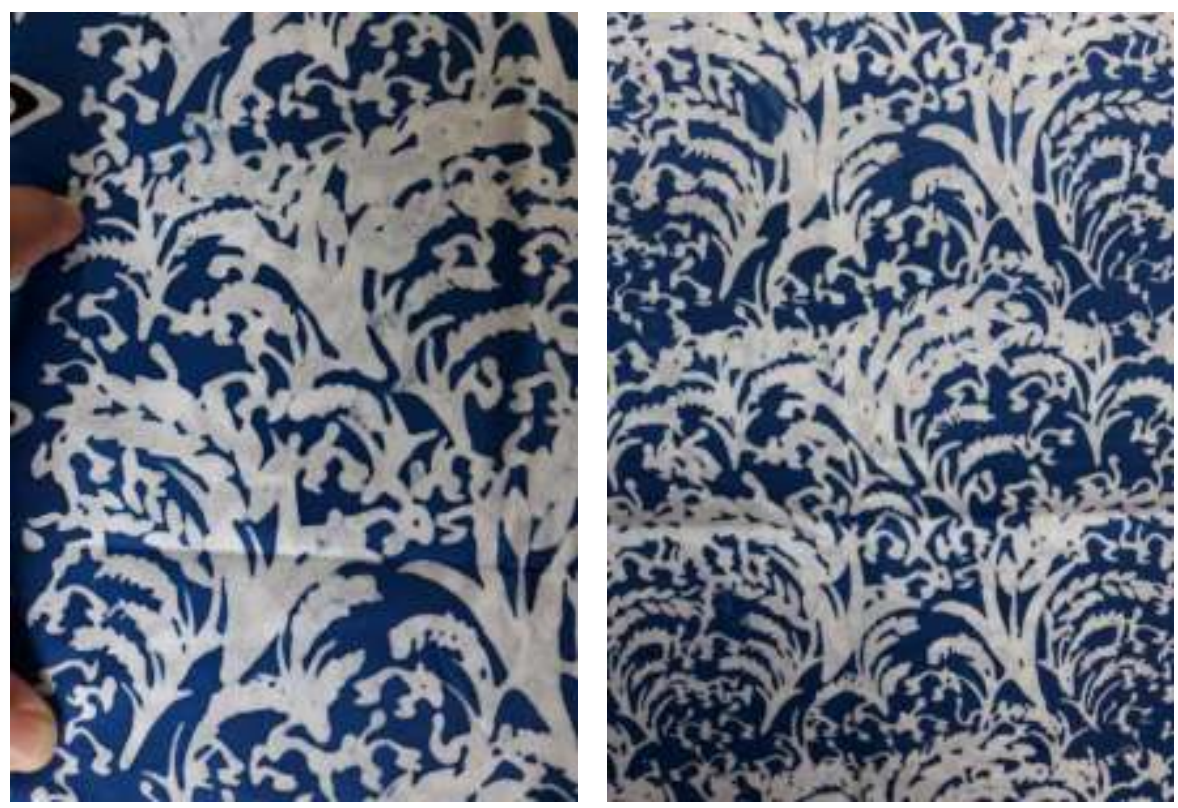

Source: Research Documents (Mujahiddin, 2020)

Figure 1. Typical Rice Paddy Batik in Pematang Johar Village 
The choice of rice in "Batik Sawah" is also due to the desire of Pematang Johar Village to campaign or popularize the word sawah in the community, which so far the word sawah is synonymous with farmers or synonymous as belonging to farmers. With the existence of "Batik Sawah", the word paddy field is no longer just the property of farmers but can already be owned by people who are not farmers. The batik work is then used as a village local wisdom by regulating it in village regulations (Perdes). The contents of the rules in Pematang Johar Perdes Number 11 of 2019 include requiring all kindergartens, elementary and middle school students as well as government agencies in the Pematang Johar Village area to be obliged to use Batik Sawah every Friday.

The explanation above shows that there is one product resulting from the construction of local knowledge. The product is then given the name Batik Sawah which is used as a local wisdom and local identity in Pematang Johar Village. The existence of this knowledge construction reinforces that a local wisdom or local knowledge is the result of community social construction; which is built, developed, perfected and maintained in the process of interaction among community members and also outside the community. The construction process is inseparable from the dialectical relationship between externalization, objectification and internalization. The externalization process was marked by an exchange of ideas to develop Pematang Johar Village as a batik village. The externalization process is also marked by determining the name of the batik and the batik pattern based on the local character of the village, namely rice fields. The objectification process was marked by a mutual agreement to make Batik Sawah the village's local wisdom by issuing Perdes Number 11 of 2019. Meanwhile, the internalization process was marked by making Batik Sawah as mandatory clothing every Friday for school students and government office workers. in Pematang Johar Village. The internalization process was also marked by the formation of a women's batik group in Dusun IX Pematang Johar Village.

It is in this internalization process that the practice of empowerment through local knowledge construction is practiced by providing training to women's groups that have been formed in IX Sub-Village, Pematang Johar Village, Deli Serdang Regency. The training provided starts from training on how to paint batik, coloring or dyeing it to batik fading. Most of the women's groups have successfully carried out all the training provided and in December 2019 they have started to carry out batik crafts independently. With this batik training, it is hoped that it can increase the empowerment of women's groups so that they can help meet household needs based on their skills, namely batik. Moreover, orders for Batik Sawah typical of Pematang Johar Village have started to increase both from within the village and from outside the village. According to the village head of Pematang Johar, so far the batik orders received by the village have always been distributed to groups of women batik who have been trained in batik studios. With this distribution to the women's batik groups, it is certainly very helpful for them because it can be an additional income for individuals and families.

On the basis of this explanation, this article is interested in analyzing the implications of local knowledge construction in the practice of empowering women's groups in the Batik Liza Mangrove Studio, Pematang Johar Village, Deli Serdang Regency. It is hoped that the writing in this article can contribute to both practical and academic levels. Women's empowerment is created because of the opportunity for entrepreneurship that is one of the pillars of society (Sarlawa and Adiwijaya, 2019). At a practical level, this paper will provide an explanation that the construction of local knowledge in women's empowerment practices has many variations and differences, especially if it is related to the local village context which has different social and cultural resources in each region. At the academic level, the concept of knowledge construction is closely related to the social construction theory put forward by Berger and Luckmann (1966) in a work entitled: The Construction of Reality. 
A Treatise in the Sociology of Knowledge. In this work, Berger and Luckmann say that reality is socially formed. The social formation of reality involves two dimensions in reality, namely the objective dimension and the subjective dimension. The two dimensions of reality shape humans through a dialectical process which in the framework of Berger and Luckmann's concept is called the process of objectification, internalization and externalization. As explained above, the dialectical framework consisting of objectification, internalization and externalization shows that the practice of empowering women is a human product and humans (read; women) are part of the object of empowerment itself.

\section{Research Methods}

The research design used a qualitative research design with a case study approach to a group of women in the Batik Liza Mangrove Studio, Pematang Johar Village, Deli Serdang Regency. This approach was deliberately chosen to be able to express in depth the process of local knowledge construction on women's empowerment practices in Pematang Johar Village, Deli Serdang Regency, to be precise at the Liza Manggrove Batik Studio. This is in accordance with what was said by Bogdan and Taylor (Kaelan: 2012) that the qualitative research method is a research procedure that produces descriptive data in the form of notes, words, and things related to meaning and value.

The data in this study were collected using in-depth interviews with each research informant. The research informants were selected using a purposive sampling approach, which is a data source sampling technique with certain considerations (Sugiyono, 2010). After the data is collected, in the next stage the data is analyzed using the interactive model data analysis technique proposed by Miles and Huberman, which consists of three main things, namely; Data reduction, data presentation, and drawing conclusions / verification, which are intertwined before, during, and after data collection in parallel form, to build general insights called analysis (Idrus, 2009).

\section{Result and Discussion}

3.1 Implications of Local Knowledge Construction in Empowerment Practices of Women's Groups in the Batik Liza Mangrove Studio, Pematang Johar Village

The women's group is still very synonymous with the status of helplessness. This form of powerlessness can be seen in the Human Development Index (HDI), the Profile of Indonesian Women (PPI) and Gender-Based Human Development. The overall index in 2018 then provided a report that the education and work aspects of women were indeed lower than that of men. For example, women aged 15 years and over, on average have studied 7.72 years, while men have studied for 8.62 years. In the economic aspect, the average per capita income of women in Indonesia is proxied with an average per capita expenditure of around 9.04 million rupiah for a year. This amount is smaller than men's per capita expenditure which reaches 15.55 million rupiah in a year (BPS, 2018).

Implicitly, the low income of women in the economic sector cannot be separated from the low involvement of women in the formal employment sector. In the 2018 PPI report, it was stated that the Women's Labor Force Participation Rate (TPAK) was only 50.89 percent compared to the TPAK for men which reached 82.51 percent. In other words, only about 5 women out of 10 working age women have the potential to work. This condition is exacerbated by 61.37 percent of women working in the informal sector and only 38.63 women working in the formal sector. On the other hand, the PPI report also explains the conditions of women in rural areas who work more as family workers with a percentage of 35.47 percent, and followed 
by work status as laborers / employees / employees with a percentage of 21, 39 percent and self-employed with a percentage of 18.68 percent. The large number of women in rural areas who have the status of family workers illustrates that within the structure of village society, men are still considered as the main breadwinners and women generally work only to help increase family income. Meanwhile, in urban areas, the status of women who work as family workers is only 12.44 percent, which means it is smaller than in rural areas.

In fact, if women are given space to access jobs - be it in the formal or informal sectors it will make a real contribution to the family. Lasswell and Lasswell in Puspitasari et al, (2013) explained that this contribution can be seen from an increase in family finances, ownership of luxury goods, and a higher standard of life with the achievement of a sense of security so that it has an impact on improving family social status. What was said by Laswell and Lasswell was confirmed by the results of previous studies such as; Dewi (2015) who states that income from women traders will really help the family when compared to only relying on the husband's income, who is identified as the backbone of the family. Puspitasari et al, (2013) in their research on the economic contribution of women horticultural farmers in Padajaya Village, Sindangjaya Village, Cianjur Regency found that the economic contribution of women in family income was 11,3 percent and this contribution is significantly related to the objective and subjective welfare of the family. Research related to the contribution and role of women in increasing family economic income also shows the same thing that women who work in the informal sector have a real impact on increasing family income (Bertham et al, 2011; Mujahiddin \& Ananda, 2017).

Efforts to increase women's participation in working in the informal sector are usually carried out through empowerment programs. The models of the women's empowerment program vary widely. There is a women's empowerment model based on the PKK Group (Pamungkas, 2013; \& Rizkia, 2017), some based on entrepreneurship and local potential development (Astuti, 2012; \& Karawati, 2017), some based on microfinance or women's savings and loans (Hasanah, 2013; and Rohmah, 2014), and the last one that is being developed is a model of empowering women's groups through the development of tourism villages (Sujarwo et al, 2017).

In the practice of empowering women's groups at the Liza Mangrove Batik Studio, it can be seen from the internalization process in the construction of local knowledge. The internalization process requires continuous efforts towards the Batik Sawah program, so that a women's group of 20 people is formed who will be targeted as batik makers who will produce Batik Sawah sustainably according to the needs and demands of the people in Pematang Johar Village and outside Pematang Johar Village. .

The batik training given to the women's batik groups makes them self-empowered in the form of authority, knowledge and abilities. This condition makes them able to fulfill their daily needs physically, economically and socially. Physically, most of the women who became batik makers said they were able to meet physical needs such as the ability to take better care of themselves, feel more confident and happy.

"After participating in the batik training and being part of the Batik Sawah batik in Pematang Johar Village, I feel more confident because now I have skills that I can use. And I also feel happier because I have activities outside of the household that I have been doing. " (Result of interview with Mrs. Juli Ana. Batik maker at Sanggar Batik Liza Mangrove).

"I personally also feel more able to take care of myself. Now I can buy some care products from my batik. Yes, at least I can buy a different and better lipstick. " (Result of interview with Mrs. Anisa Fitri. Batik maker at Batik Liza Mengrove Studio) 
Meanwhile, economically, the women batik makers admit that the batik they receive has succeeded in helping the family's economic income, and they feel they have an equal economic opportunity with others. A sense of having equal economic opportunity with other people because they feel they have a special ability that not everyone has, namely the ability to make batik. According to Rahma as the owner of the Liza Mangrove Batik Studio, some of them are already independent without having to be supervised in the batik making process. For those who are able to be independent, they still have capital constraints because to build a batik workshop or place requires capital.

"There are some that still need to be watched. Usually every time the process is colored or melted they will still ask questions and we will keep an eye on them. Some have succeeded, but are still unable to be independent and find their own markets because to have their own batik studio requires capital. Likewise, economically, the batik activities they do provide economic benefits for them and their families. " (Results of Interview with Mrs. Rahma, Founder of Batik Liza Mangrove Studio, Pematang Johar Village)

On the social aspect, the batik training given to the women's batik groups in Pematang Johar Village has succeeded in increasing their awareness of the importance of being part of the promotion of batik culture. Most of these women batik makers admit that they feel involved in the processes of socio-cultural development and feel they have a role in the promotion of batik culture, especially Batik Sawah, which is the typical batik of Pematang Johar Village.

"By participating in the batik training yesterday, apart from gaining knowledge and skills in batik, I also feel involved in the process of cultural development. From this, my knowledge about the importance of cultural promotion took shape. "(Result of an interview with Mrs. Mardiani. The batik maker at the Liza Mengrove Batik Studio)

The explanations above show the implications of local knowledge construction from rice field batik on community empowerment practices. This implication can be seen from the formation of the ability of women's batik groups to meet their daily needs both physically, economically and socially resulting from empowerment practices that have provided knowledge and abilities in making batik work, especially Batik Sawah (See Figure 1)

\begin{tabular}{|l|l|l|}
\cline { 2 - 2 } \multicolumn{2}{l|}{} & $\begin{array}{l}\text { Physically: There is the ability } \\
\text { to take care of yourself }\end{array}$ \\
$\begin{array}{l}\text { Internalization Providing Training for Women } \\
\text { Pickers }\end{array}$ & Ability to meet the needs of life & $\begin{array}{l}\text { Economically: Helping to } \\
\text { increase family economic } \\
\text { income and feel they have the } \\
\text { same economic opportunity. }\end{array}$ \\
\hline & $\begin{array}{l}\text { Socially: Increased awareness } \\
\text { of the importance of being part } \\
\text { of the promotion of batik } \\
\text { culture. }\end{array}$ \\
\hline
\end{tabular}

* Source: Processed from the results of research (Mujahiddin, 2020)

Figure 2. Implications of Local Knowledge Construction of Batik Sawah on Empowerment Practices of Women's Groups 


\subsection{The Impact of Women's Empowerment Practices at Batik Liza Mangrove Studio in Improving Family Welfare in Pematang Johar Village}

In general, the practice of empowering women at Sanggar Batik Liza Mangrover has succeeded in helping women's groups to contribute in meeting the primary needs of the family, especially food and clothing needs. They usually allocate income from batik to spend on family food needs. If the food needs are fulfilled, the source of income from batik is diverted to meet clothing needs.

"Usually for kitchen needs, please help your husband. His name is also a small husband's income so we can help. If the kitchen needs are met, we usually switch to something else, can buy clothes for school children, pay their school fees when the due date. (Result of interview with Mrs. Endang. Batik maker at Batik Liza Mengrove Studio)

According to the women's batik group at the Liza Mangrove Batik Studio, the income they generate from batik activities is indeed very helpful for their families from an economic perspective. Sometimes according to them, the income from batik they receive every week can be used to pay fees, fees or basic electricity tariffs every month.

"So it can be used for anything. It really depends on what urgent needs must be paid that week. Sometimes we also use it to pay for electricity. "(Result of interview with Mrs. Juli Ana. Batik maker at Batik Liza Mengrove Studio)

Even though they are only able to help meet the family's primary needs such as clothing and food, according to the women's batik group at the Liza Manggrove Batik Studio, the income they receive from batik activities has made them feel happy because they have income that can be used to help their family. This condition certainly illustrates that the impact of the women's empowerment practice at the Liza Manggrove Batik Studio has only succeeded in improving family welfare subjectively and has not been able to objectively increase family welfare. This is because the income generated from batik activities can only be used to meet the primary needs of the family and has not been able to meet other needs.

It's just that, from their subjective welfare perspective, the income from making batik has succeeded in giving them satisfaction because this income is very useful in meeting their family's needs. The increase in family welfare subjectively for the women's batik group at the Liza Manggrove Batik Studio is certainly not a negative thing because the nature of welfare is very subjective, which is highly dependent on the value and meaning it gives. So that in subjective welfare, family welfare is closely related to the level of income and the level of satisfaction from consuming the income received.

\section{Conclusion}

Based on the results of the discussion above, it can be concluded that the batik training given to the women's batik groups makes them self-empowered in the form of authority, knowledge and abilities. This condition makes them able to fulfill their daily needs physically, economically and socially. The impact of the practice of empowering women at the Liza Manggrove Batik Studio has only succeeded in improving family welfare subjectively. This is because the income generated from batik activities can only be used to meet the primary needs of the family and has not been able to meet other needs. 


\section{Acknowledgment}

The publication of articles in this journal is the result of research funded by the 20192020 Muhammadiyah University of North Sumatra APB funds. In addition, the team of writers would also like to thank the Pematang Johar Village Government, the women's group of batik makers and the Liza Mangrove Batik Studio who have been willing to become sources or informants in the research.

\section{References}

Astuti, Mulia. (2012). Pemberdayaan Perempuan Miskin Berbasis Pemanfaatan Sumberdaya Lokal Melalui Pendekatan Sosial Enterpreneurship: Studi Kasus di Daerah Tertinggal, Kabupaten Pasaman, Sumatera Barat. Sosiokonsepsia. Vol 17, No 3, Tahun 2012 (pp 241-251). Doi: https://doi.org/10.33007/ska.v17i3.829

Berger, Peter L \& Thomas Luckmann. (1966). The Social Construction of Reality. A Treatise in The Sociology of Knowledge. New York: Doubleday \& Company Inc.

Bertham dkk. (2011). Peranan Perempuan Dalam Perekonomian Keluarga Dengan Memanfaatkan Sumberdaya Pertanian. AGRISEP. Vol 10, No 1, Maret 2011 (pp 138153). Doi: https://doi.org/10.31186/agrisep.10.1.138-153

BPS. (2018). Indeks Pembangunan Manusia. Jakarta: Badan Pusat Statistik.

Dewi, Dian Ayu Liana. (2015). Peran Ibu Rumah Tangga Dalam Perekonomian Keluarga Studi Kasus Di Desa Gunem Kabupaten Rembang. Bulutin Bisnis \& Manajemen. Vol 01, No 01, Pebruari 2015 (pp 38-45). Diambil dari: http://journal.stieyppi.ac.id/index.php/BBM/article/view/112

Hasanah, Siti. (2013). Pemberdayaan Perempuan Melalui Kegiatan Ekonomi Berkeadilan: Simpan Pinjam Syariah Perempuan. SAWWA: Jurnal Studi Gender. Vol 9, No 1, Oktober 2013 (pp 71- 88). Doi: http://dx.doi.org/10.21580/sa.v9i1.666

Hendryantoro, Anggun. (2014). Pemberdayaan Masyarakat Melalui Pengembangan Desa Wisata dan Implikasinya Terhadap Ketahanan Sosial Budaya: Studi di Desa Wisata Brayut Pandowoharjo, Kecamatan Sleman, Kabupaten Sleman, D.I. Yogyakarta. Jurnal Ketahanan Nasional. Vol 20, No 2, Agustus 2014 (pp 49-57). Doi: https://doi.org/10.22146/jkn.6785

Idrus, Muhammad. 2009. Metode Penelitian Ilmu Sosial; Pendekatan Kualitatif dan Kuantitatif. (Edisi Kedua). Jakarta: Penerbit Erlangga.

Ife, Jim \& Frank Tesoriero. (2008). Community Development; Alternatif Pengembangan Masyarakat di Era Globalisasi. (Edisi Ketiga). Yogyakarta: Pustaka Pelajar.

Kaelan, M.S, Prof.,DR.. 2012. Metode Penelitian Kualitatif Interdisipliner bidang Sosial, Budaya, Filsafat, Seni, Agama dan Humaniora. Yogyakarta: Penerbit Paradigma.

Karawati, Lilis. (2017). Pemberdayaan Perempuan Melalui Pelatihan Kewirausahaan Berbasis Potensi Alam Setempat. Jurnal Ilmiah VISI. Vol 12, No 1, Juni 2017 (pp 45-52). Doi: https://doi.org/10.21009/JIV.1201.5

Kementerian PPA. (2018). Profil Perempuan Indonesia. Jakarta: Kementerian Pemberdayaan Perempuan dan Perlindungan Anak

Mujahiddin \& Ananda Mahardika. (2017) Perempuan dan Kemiskinan: Strategi dalam Memenuhi Kebutuhan Keluarga. Medan: UMSU Press.

Mustangin dkk. (2017). Pemberdayaan Masyarakat Berbasis Potensi Lokal Melalui Program Desa Wisata di Desa Bumiaji. SOSIOGLOBAL. Vol 2, No 1, Desember 2017 (pp 5972). Diambil dari: http://jurnal.unpad.ac.id/sosioglobal/article/view/15282/7204 
Pamungkas, Nurendra Satya. (2013). Pemberdayaan Perempuan Melalui Kesenian Karawitan di Bejiharjo Karangmojo Gunungkidul. DiKLUS. Vol 17, No 1, Maret 2013 (pp 200209). Diambil dari: https://journal.uny.ac.id/index.php/diklus/article/view/2890

Puspitasari, Novi dkk. (2013). Peran Gender, Konstribusi Ekonomi Perempuan, Dan Kesejahteraan Keluarga Petani Hortikultura. Jurnal Ilmu Kelurga \& Konsumen. Vol 6, No 1, Januari 2013 (pp 10-19). Doi: https://doi.org/10.24156/jikk.2013.6.1.10

Rizkia, Frida Nur. (2017). Peran Perempuan Dalam Meningkatkan Perekonomian Keluarga Melalui Program P2WKSS di Sumber Gamol, Balecatur, Gamping, Sleman. Social Studies. Vol 6, No 4, Tahun 2017 (pp 406-418). Diambil dari: http://journal.student.uny.ac.id/ojs/index.php/social-studies/article/view/8970

Rohmah, Siti. (2014). Model Pemberdayaan Ekonomi Perempuan Melalui Grassroot Microfinance Syariah. SAWWA: Jurnal Studi Gender. Vol 10, No 1, Oktober 2014 (pp 59-82). Doi: http://dx.doi.org/10.21580/sa.v10i1.630

Sarlawa, R., and Adiwijaya, S. (2019). Local Wisdom-Based Women's Empowerment: Study of Rattan Weaving Craftsmen in the Betang Asi Credit Union Cooperative Business Group in Pulang Pisau Regency, Central Kalimantan Province. Budapest International Research and Critics Institute-Journal (BIRCI-Journal). P. 31-38.

Sugiyono. 2010. Metode Penelitian Kuantitatif, Kualitatif dan R\&D. Bandung: Penerbit Alfabeta.

Suharto, Edi. (2009). Membangun Masyarakat Memberdayakan Rakyat; Kajian Strategis Pembangunan Kesejahteraan Sosial \& Pekerjaan Sosial. Bandung: Refika Aditama

Sujarwo dkk,. (2017). Pendidikan Berbasis Komunitas Untuk Pemberdayaan Perempuan Di Desa Wisata. Jurnal Pendidikan. Vol 1, No 2, November 2017 (pp 361-373). Doi: https://doi.org/10.21831/jpipfip.v10i1.16798 